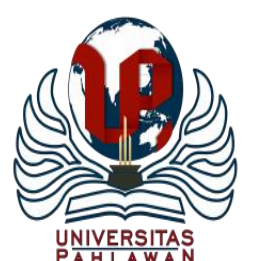

Jurnal Basicedu Volume 5 Nomor 1 Tahun 2021 Halaman 227- 238

JURNAL BASICEDU

Research \& Learning in Elementary Education

https://jbasic.org/index.php/basicedu

\title{
Peran Orang Tua dan Keluarga dalam Penanganan Anak dengan Gangguan Komunikasi (Bicara atau Bahasa)
}

\author{
Uyu Mu'awwanah ${ }^{1}$, Asep Supena ${ }^{2}$ \\ Program Studi Pendidikan Islam Anak Usia Dini, Fakultas Tarbiyah dan Keguruan, \\ Universitas Sultan Maulana Hasanuddin Banten ${ }^{1}$ \\ Program Pascasarjana, Fakultas Ilmu Pendidikan, Universitas Negeri Jakarta ${ }^{2}$ \\ E-mail: uyu.muawanah@uinbanten.ac.id ${ }^{1}$ supena2007@yahoo.com $^{2}$
}

\begin{abstract}
Abstrak
Orang tua dan keluarga merupakan faktor penting dalam proses penanganan anak dengan gangguan komunikasi (bicara dan bahasa). Oleh karena itu artikel ini mendeskripsikan terkait peran orang tua dan keluarga dalam penanganan terhadap anak dengan gangguan komunikasi (bicara atau bahasa), tidak hanya secara umum dan khusus tetapi juga secara teoritis dan praktis. Mengkaji peran, orang tua, keluarga dan anak dengan gangguan komunikasi (bicara atau bahasa), pengertian gangguan bicara atau bahasa (speech or language disorder), dampak gangguan bicara dan bahasa pada anak, klasifikasi gangguan komunikasi (bicara atau bahasa), penyebab gangguan atau keterlambatan bicara, deteksi dini keterlambatan bicara dan bahasa pada anak, anak dengan gangguan komunikasi (bicara atau bahasa), peran orang tua dan keluarga terhadap anak dengan gangguan komunikasi (bicara atau bahasa), penanganan speech or language disorder pada anak, dan pendidikan khusus untuk penderita speech or language disorder.
\end{abstract}

Kata kunci: studi deskriptif, peran orang tua dan keluarga, gangguan komunikasi.

\section{Abstract}

Parents and family are important factors in the process of handling children with communication disorders (speech and language disorders). Therefore this article describes the role of parents and families in handling children with communication disorders (speech or language disorders), not only in general and specifically but also theoretically and practically. Assessing the role, parents, family and children with communication disorders (speech or language disorders), understanding of speech or language disorders, the impact of speech and language disorders on children, classification of communication disorders (speech or language disorders), causes of disorders or speech delays, early detection of speech and language delays in children, children with communication disorders (speech or language disorders), the role of parents and families towards children with communication disorders (speech or language disorders), handling speech or language disorders in children, and special education for sufferers speech or language disorder.

Keywords: study descriptive, role of parents and family, communication disorders.

Copyright (c) 2021 Uyu Mu'awwanah, Asep Supena

$\triangle$ Corresponding author :

Address : Universitas Sultan Maulana Hasanuddin Banten

ISSN 2580-3735 (Media Cetak)

Email : uyu.muawanah@uinbanten.ac.id

ISSN 2580-1147 (Media Online)

Phone : Nomor HP Penulis

DOI : $\quad$ https://doi.org/10.31004/basicedu.v5i1.620 
228 Peran Orang tua dan Keluarga dalam Penanganan Anak dengan Gangguan Komunikasi (Bicara atau Bahasa)- Uyu Mu'awwanah, Asep Supena

DOI : https://doi.org/10.31004/basicedu.v5i1.620

\section{PENDAHULUAN}

Berkomunikasi tampaknya menjadi kebutuhan dasar manusia. Komunikasi dimulai sejak bayi bekerja untuk membuat kebutuhannya diketahui orang tua. Awalnya, bayi menggunakan tangisan, gerutuan, gerak tubuh, dan ekspresi wajah untuk menyampaikan pesan. Pada usia 3 atau 4 bulan, bayi mulai menderu-deru dan ocehan dengan menggunakan suara yang mendekati ucapan dan meniru bahasa bayi telah didengarkan sejak lahir. Akhirnya, sekitar 1 tahun, "kata" pertama muncul. Kata pertama ini biasanya merupakan pengulangan suara, seperti ma-ma, dada, atau pa-pa. Jadi, apakah mengherankan jika dalam banyak bahasa kata-kata ini berarti "ibu" dan/atau "ayah"? Tidak ada yang lebih menarik bagi orang tua selain bayi mereka yang menakjubkan kemampuan untuk memperoleh ucapan dan bahasa di tahun pertama kehidupan.

Ketika seorang anak menunjukkan keterlambatan dalam perkembangan bahasa atau mengalami kesulitan memproduksi suara ucapan, intervensi dini sangat penting untuk meningkatkan kemampuannya untuk berkomunikasi. Gangguan perkembangan berbahasa adalah ketidakmampuan atau keterbatasan dalam menggunakan simbol linguistik untuk berkomunikasi secara 2 verbal atau keterlambatan kemampuan perkembangan bicara dan bahasa anak sesuai kelompok umur, jenis kelamin, adat istiadat, dan kecerdasannya. Masalah gangguan pada tumbuh kembang anak semakin sering dijumpai belakangan ini. Contohnya seperti keterlambatan perkembangan motorik halus dan kasar, berbicara, kognisi, personal, kemampuan melakukan aktivitas seharihari, serta sosial.

Dalam suatu keluarga peran orang tua sangatlah penting bagi seseorang anak, hal tersebut dikarenakan dengan peran yang dimiliki oleh orang tua tersebut maka akan dapat mempengaruhi perilaku anak. Ketika anak ingin berperilaku, maka anak tersebut akan menyesuaikan perilakunya dengan perilaku orang-orang di sekitarnya. Berdasarkan hasil penelitian (Jauhari \& Rafikayati, 2019) peran orang tua untuk mengembangkan potensi psikomotor, kognitif maupun potensi afektif, di samping itu orang tua juga harus memelihara jasmaniah anak. Setiap orang tua tentu akan memiliki perasaan berbahagia dan bangga bila memiliki anak sehat, cerdas, seperti kebanyakan anak lainya, namun bagaimana dengan perasaan orang tua yang memiliki anak kebutuhan khusus, bagi orang tua anak berkebutuhan tersendiri, dan tidak dapat disamaratakan dengan orang tua lainnya. Keberadaan orang tua bagi anak dengan gangguan komunikasi (bicara atau bahasa) memiliki makna yang berarti bagi proses perlindungan dan tumbuh kembangnya. Oleh karena itu, pengetahuan dan peningkatan kapasitas orang tua, dalam menghadapi anak dengan gangguan komunikasi (bicara atau bahasa) sejak dini akan memberikan dampak signifikan dalam merawat, memelihara, mendidik, dan meramu bakat atau potensi yang dimiliki setiap anak dengan gangguan komunikasi (bicara atau bahasa). Kesiapan dan kesiagaan orang tua yang dihadapkan anak dengan gangguan komunikasi (bicara atau bahasa) merupakan kunci sukses penanganan, ditambah dukungan dari 
229 Peran Orang tua dan Keluarga dalam Penanganan Anak dengan Gangguan Komunikasi (Bicara atau Bahasa)- Uyu Mu'awwanah, Asep Supena

DOI : https://doi.org/10.31004/basicedu.v5i1.620

masyarakat dan pemerintah dalam menyediakan lingkungan dan fasilitas yang ramah terhadap anak berkebutuhan khusus dengan gangguan komunikasi (bicara atau bahasa).

Dalam menangani anak-anak dengan gangguan komunikasi (bicara atau bahasa), orang tua memerlukan pengetahuan tentang anak-anak tersebut, keterampilan mengasuh dan melayaninya. Anak dengan gangguan komunikasi (bicara atau bahasa) perlu mendapat dorongan, tuntunan, dan praktik langsung secara bertahap. Potensi yang dimiliki anak-anak berkebutuhan khusus akan tumbuh berkembang seiring dengan keberhasilan peran orang tua dalam memahami dan memupuk potensi anak-anak tersebut.

\section{METODE}

Penelitian ini menggunakan pendekatan kualitatif dengan metode deskriptif. Penelitian kualitatif dengan metode deskriptif adalah metode yang menjelaskan atau mendeskripsikan suatu fakta, data, dan objek penelitian secara sistematis dan sesuai dengan situasi alamiah. Terkait hal yang diteliti, hasil penelitian lebih menekankan pada makna daripada hasil, dan hasil penelitian tidak mengikat serta dapat berubah sesuai dengan kondisi yang dihadapi di lapangan penelitian dan diinterpretasikan dan dituliskan dalam bentuk katakata atau deskriptif berdasarkan fakta di lapangan (Anggito \& Setiawan, 2018).

Peneliti berperan sebagai human instrument (peneliti melakukan penelitiannya sendiri). Pengambilan sampel dan sumber data dilakukan secara purposive sampling (pengambilan sampel berdasarkan atas sebuah pertimbangan yang berfokus pada tujuan tertentu dan peneliti sudah menentukan sebuah kriteria pada pengambilan sampelnya), pengambilan sampel berdasarkan kebutuhan dan sesuai dengan topik penelitian. Teknik pengumpulan data menggunakan wawancara, observasi, dan dokumentasi. Analisis data bersifat kualitatif, dengan menggunakan model Milles \& Huberman. Pemeriksaan keabsahan data, menggunakan triangulasi teknik, meningkatkan ketekunan, dan menggunakan bahan referensi.

Sumber data dalam penelitian adalah subjek mengenai perolehan data yang telah didapat. Datadata yang kemudian dijadikan acuan dalam penelitian ini diambil dari berbagai sumber di antaranya:

1) Sumber Data Primer

Data primer merupakan data yang diperoleh langsung dari subjek yang diteliti, dalam mengumpulkan data primer, peneliti harus kontak atau komunikasi langsung dengan subjek ataupun informan dalam penelitian, maka dari itu, pada penelitian ini sumber data yang didapatkan berasal dari subjek atau informan yang akan diwawancarai dan diobservasi oleh peneliti yang dilakukan langsung di tempat penelitian.

2) Sumber Data Sekunder

Data sekunder merupakan data pelengkap untuk mendukung data primer.

Teknik analisis data yang digunakan dalam penelitian ini adalah menggunakan model Milles dan Huberman, yaitu analisis dalam penelitian dilakukan secara interaktif. 
230 Peran Orang tua dan Keluarga dalam Penanganan Anak dengan Gangguan Komunikasi (Bicara atau Bahasa)- Uyu Mu'awwanah, Asep Supena

DOI : https://doi.org/10.31004/basicedu.v5i1.620

1) Reduksi Data (Reduction)

Peneliti menulis ulang atau merangkum hasil data yang didapatkan pada dari hasil observasi, wawancara, dan dokumentasi. (Milles \& Huberman, 2013)

2) Penyajian Data (Data Display)

Setelah mereduksi data, langkah selanjutnya adalah melakukan penyajian data (display data). Data yang diperoleh dalam penelitian ini disajikan dalam bentuk uraian singkat yang bersifat naratif (dengan teks) (Milles \& Huberman, 2013).

3) Penarikan Kesimpulan (Verification)

Langkah terakhir pada analisis data adalah membuat kesimpulan. Peneliti akan menarik atau membuat kesimpulan dengan memberikan penjelasan dari kegiatan pengambilan data melalui observasi, wawancara, dan didukung oleh dokumentasi. (Milles \& Huberman, 2013).

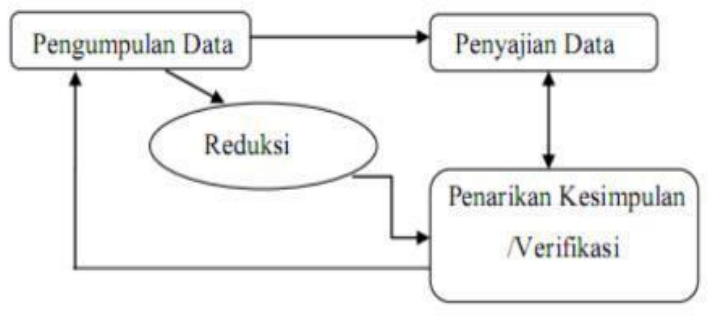

Gambar 1. Analisis Data Interaktif model Hubberman dan Miles

Teknik pemeriksaan keabsahan data yang digunakan oleh peneliti dalam penelitian ini, sebagai berikut:

1) Triangulasi Teknik

Triangulasi teknik digunakan untuk menguji kredibilitas data yang dilakukan dengan cara mengecek data kepada sumber yang sama dengan cara yang berbeda, misalnya peneliti sudah melakukan wawancara, data yang didapatkan melalui wawancara lalu dicek lagi dengan observasi secara langsung, kemudian melakukan dokumentasi (Sugiyono, 2018).

2) Meningkatkan Ketekunan

Meningkatkan ketekunan berarti melakukan pengamatan secara lebih cermat dan berkesinambungan, dengan cara tersebut maka kepastian data yang sudah didapatkan oleh peneliti dan urutan peristiwa akan direkam secara pasti dan sistematis (Sugiyono, 2018).

3) Menggunakan Bahan Referensi

Bahan referensi disini adalah dengan adanya bukti pendukung untuk memperkuat dan membuktikan data yang sudah ditemukan di lapangan penelitian. (Moleong, 2017) .

\section{HASIL DAN PEMBAHASAN}

\section{Peran, Orang Tua, Keluarga dan Anak dengan} Gangguan Komunikasi (Bicara atau Bahasa)

Peran adalah seperangkat perilaku interpersonal, sifat dan kegiatan yang berhubungan dengan individu dalam posisi satuan tertentu. Menurut tata bahasa, orang tua adalah ayah, ibu kandung, orang yang dianggap tua, atau orang yang dihormati atau disegani. Markum dalam Ritzer (2008), lingkungan yang pertama dikenal oleh individu (anak) adalah orang tua yang terdiri dari ayah dan ibu. Maka dengan sendirinya ayah dan ibu sangat menentukan pertumbuhan dan perkembangan kepribadian seseorang anak. 
231 Peran Orang tua dan Keluarga dalam Penanganan Anak dengan Gangguan Komunikasi (Bicara atau Bahasa)- Uyu Mu'awwanah, Asep Supena

DOI : https://doi.org/10.31004/basicedu.v5i1.620

Orang tua merupakan kelompok sosial yang pertama dalam kehidupan manusia, tempat ia belajar dan menyatakan diri sebagai makhluk sosial di dalam hubungan interaksinya dengan kelompoknya. Sementara Soekanto (2006) menyatakan bahwa orang tua adalah lembaga kesatuan sosial terkecil yang secara kodrati berkewajiban mendidik anaknya. Orang tua mendidik anak secara tradisional dan turun temurun. Selain itu Kartono dalam Ritzer (2008) menyatakan bahwa orang tua merupakan unit sosial terkecil yang memberikan fondasi primer bagi perkembangan anak.

Setiap anggota keluarga mempunyai peran masing-masing. Sebuah keluarga tidak selamanya mendapatkan anak yang terlahir sempurna atau dalam kondisi normal, akan ada dimana anak lahir dengan kondisi mengalami gangguan atau abnormalitas. Orang tua yang memiliki anak dengan gangguan komunikasi (bicara atau bahasa), tentu akan mengalami tekanan emosional. Tekanan emosional terbesar biasanya dialami oleh orang tua ketika pertama kali mengetahui bahwa anak mereka didiagnosa mengalami gangguan komunikasi (bicara atau bahasa). Sangat sulit bagi mereka untuk memahami situasi baru. Ada berbagai macam situasi ketika seseorang mendengarkan berita yang tidak diinginkan, seperti reaksi shock, tidak percaya bahwa hal itu terjadi pada diri atau keluarganya. Pada saat ini keluarga membutuhkan dukungan dan masukan untuk langkah penanganan awal bagi anak yang berkebutuhan khusus tersebut.

Anak berkebutuhan khusus adalah anak yang memiliki perbedaan dengan anak-anak pada umumnya. Anak berkebutuhan khusus (dulu disebut dengan anak luar biasa) didefinisikan anak yang memerlukan pendidikan dan layanan khusus untuk mengembangkan potensi kemanusiaan mereka secara sempurna (Hallahan, 2003). Anak yang berkebutuhan khusus akan mengarah pada keterlambatan dan gangguan pada perkembangan dan tumbuh kembangnya.

\section{Pengertian Gangguan Bicara atau Bahasa} (Speech or Language Disorder)

Samuel Kirk, dkk (2009) mengemukakan speech or language disorder adalah gangguan bicara dan bahasa, atau sering juga disebut sebagai ketidakmampuan untuk mengkode sebuah informasi, dapat berupa keterlambatan bahasa reseptif, ekspresif atau keduanya. Serta terjadi pula gangguan komunikasi yang mengganggu kemampuan individu untuk mengirim, menerima, dan memproses informasi. Keterlambatan bicara atau bahasa merupakan masalah/gangguan perkembangan yang paling sering dijumpai (5$10 \%$ kasus pada anak prasekolah).

Kelainan atau gangguan bahasa merupakan salah satu jenis kelainan dalam komunikasi dengan indikasi seseorang mengalami gangguan dalam proses simbolis. Kelainan atau gangguan bahasa merupakan salah satu jenis kelainan dalam komunikasi dengan indikasi seseorang mengalami gangguan dalam proses simbolis. Kesulitan ini mengakibatkan seseorang tidak mampu untuk memberikan simbol atau lambang yang diterima dan sebaliknya tidak mampu mengubah konsep pengertian menjadi simbol-simbol yang dapat dimengerti oleh orang lain. Jika seseorang tidak 
232 Peran Orang tua dan Keluarga dalam Penanganan Anak dengan Gangguan Komunikasi (Bicara atau Bahasa)- Uyu Mu'awwanah, Asep Supena

DOI : https://doi.org/10.31004/basicedu.v5i1.620

dapat berkomunikasi dengan sesamanya secara sempurna maka mereka dapat dikatakan mengalami gangguan atau kelainan bahasa. Gangguan bahasa dapat terjadi jika komunikasi seseorang menyimpang jauh dari bahasa yang digunakan oleh anak normal.

Secara klinis seorang anak disebut mengalami keterlambatan bicara apabila pada umur 2 tahun hanya dapat mengucapkan kurang dari 50 kata dan/atau belum ada kalimat yang terdiri dari kombinasi dua kata. Prevalens keterlambatan perkembangan bicara mencapai $15 \%$ pada anak berumur 2 tahun. Umumnya orang tua sudah mengeluh mengenai keterlambatan bicara pada umur 2 tahun, namun sebagian dokter memilih "menunggu" berdasarkan fakta bahwa perkembangan bicara masih sangat bervariasi pada umur 2 tahun, 50\% anak yang mengalami keterlambatan bicara akan mengejar keterlambatan tersebut pada umur 3 tahun, dan bila keterlambatan bicara hanya disebabkan oleh keterlambatan perkembangan (maturational delay), prognosisnya cukup baik (Hardiono).

Meskipun demikian, harus diingat bahwa keterlambatan bicara yang semula diduga hanya merupakan keterlambatan perkembangan ternyata dapat merupakan gejala dari gangguan lain yang lebih serius, misalnya gangguan pendengaran, retardasi mental, autisme, dan lain-lain. Keterlambatan bicara juga dapat merupakan gejala dari defisit spesifik kemampuan berbahasa yang disebut sebagai Specific Language Impairment (SLI). Keadaan ini seringkali menetap sampai usia sekolah dan dapat menyebabkan kurangnya kemampuan akademis dan menimbulkan berbagai masalah psikososial.

Kemampuan bicara dan komunikasi juga dipengaruhi tingkat intelegensi, motorik dan sosial emosionalnya. Sebaliknya, kemampuan bicara dan bahasa juga akan mempengaruhi perkembangan intelegensinya. Dengan kata lain, kemampuan anak dalam berbicara dan berkomunikasi banyak dipengaruhi oleh potensi intelegensinya (kognitif). Anak yang mengalami ketertinggalan perkembangan bicara dan bahasa akan mengalami ketertinggalan berbagai proses yang dibutuhkan dalam rangka pengembangan potensi intelegensinya. Pada sekolah dasar akan banyak dibutuhkan pemahaman bahasa dan anak akan mengalami kesulitan seperti sering salah menginterpretasikan instruksi, salah memberikan jawaban atau jenis-jenis kesulitan lainnya. Azwar (2013), mengemukakan perkembangan bicara dan bahasa mempengaruhi perkembangan anak secara global selanjutnya seperti perkembangan intelegensi, sosial emosional, keterampilan bersosialisasi, konsep diri, perilaku dan prestasi akademik.

\section{Deteksi Dini Keterlambatan Bicara dan Bahasa pada Anak}

Hubungi dokter anak bila dicurigai ada gangguan perkembangan kemampuan bahasa pada anak, dengan gejala-gejala sebagai berikut:

1. Pada usia 6 bulan, anak tidak mampu memalingkan mata serta kepalanya terhadap suara yang datang dari belakang atau samping. 
233 Peran Orang tua dan Keluarga dalam Penanganan Anak dengan Gangguan Komunikasi (Bicara atau Bahasa)- Uyu Mu'awwanah, Asep Supena

DOI : https://doi.org/10.31004/basicedu.v5i1.620

2. Pada usia 10 bulan, anak tidak memberi reaksi terhadap panggilannya sendiri.

3. Pada usia 15 bulan, anak tidak mengerti dan memberi reaksi terhadap kata-kata jangan, dada, dan sebagainya.

4. Pada usia 18 bulan, anak tidak dapat menyebut sepuluh kata tunggal.

5. Pada usia 21 bulan, anak tidak memberi reaksi terhadap perintah (misalnya duduk, kemari, berdiri).

6. Pada usia 24 bulan, anak tidak dapat menyebut bagian-bagian tubuh dan belum mampu menengahkan ungkapan yang terdiri dari 2 buah kata.

7. Setelah usia 24 bualan, anak hanya mempunyai perbendaharaan kata yang sangat sedikit atau tidak mempunyai katakata huruf $\mathrm{z}$ pada frasa.

8. Pada usia 30 bulan, ucapannya tidak dapat dimengerti oleh anggota keluarga.

9. Pada usia 36 bulan, ucapan anak tidak dimengerti oleh orang di luar keluarganya. Anak belum dapat menggunakan kalimatkalimat sederhana. Sehingga tidak dapat bertanya dengan kalimat tanya sederhana.

10. Pada usia 3,5 tahun, anak selalu gagal untuk menyebut kata akhir (ca untuk cat, ba untuk ban dan lain-lain).

11. Setelah 4 tahun, anak tidak lancar berbicara (gagap).

12. Setelah usia 7 tahun, anak masih ada kesalahan ucapan.

13. Pada usia berapa saja terdapat hipernasalitas atau hiponasalitas (sengau/bindeng) yang nyata atau mempunyai suara yang monoton tanpa berhenti, sangat keras dan tidak dapat didengar serta terus menerus memperdengarkan suara serak, (Aulia Fadhil, 2010: 82).

William Surya Hartanto mengemukakan, selain tenaga pendidik anak usia dini, tenaga medis, dan profesi lainnya dapat mengidentifikasi risiko keterlambatan bicara dan bahasa pada anakanak berdasarkan laporan orang tua. Rujukan segera ke ahli patologi bahasa dianjurkan jika orang tua khawatir anaknya memiliki masalah bicara dan bahasa atau jika ada faktor risiko tambahan. Sebaliknya, jika orang tua tidak khawatir dan tidak ada faktor risiko tambahan, pemantauan (watchful waiting) direkomendasikan untuk anak-anak yang belum dapat membuat gabungan kata-kata atau yang memiliki kosakata terbatas (di bawah 40 kata) di usia 24 bulan (2018: 546)

\section{Peran Orang Tua dan Keluarga terhadap Anak dengan Gangguan Komunikasi (Bicara atau Bahasa)}

Dalam keluarga orang tua sangat berperan sebab dalam kehidupan anak waktunya sebagian besar dihabiskan dalam lingkungan keluarga apalagi anak masih di bawah pengasuhan atau anak usia sekolah dasar yaitu antara usia (0-12 tahun), terutama peran seorang ibu. Orang tualah yang bertugas mendidik. Dalam hal ini (secara umum) baik potensi psikomotor, kognitif maupun potensi afektif, di samping itu orang tua juga harus memelihara jasmaniah mulai dari memberi makan dan penghidupan yang layak.

Kretschmer (1978), Ling (1990) dan Ross 
234 Peran Orang tua dan Keluarga dalam Penanganan Anak dengan Gangguan Komunikasi (Bicara atau Bahasa)- Uyu Mu'awwanah, Asep Supena

DOI : https://doi.org/10.31004/basicedu.v5i1.620

(1990) dalam Estabrooks (1994 : 20) menambahkan bahwa khususnya anak tunarungu lebih mudah belajar bahasa jika dalam aktivitas yang dekat dengan orang tua dan pengasuh. Merupakan tugas orang tua untuk memberikan kekayaan interaksi bahasa lisan pada anak karena orang tua berada di samping anak dari bangun tidur sampai tidur kembali. Sebagai pemain kunci, mereka perlu mengembangkan pemahaman berbagai tahapan meliputi tahapan mendengarkan, berbicara, bahasa, dan kognisi. Jadi keberhasilan anak tergantung peran serta orang tua agar aktif dalam menangani anak.

$$
\text { Sunardi dan Sunaryo (2007 : 48) }
$$
menyatakan bahwa orang tua adalah lingkungan terdekat dengan anak, paling mengetahui kebutuhan khususnya, paling berpengaruh, dan paling bertanggung jawab terhadap anaknya, sedangkan fungsi tenaga ahli lebih sebagai konsultan atau salah satu "social support" bagi keberhasilan anaknya. Bronfrenbrenner dalam Sunardi dan Sunaryo (2007:18) menambahkan bahwa keluarga merupakan altar pertama bagi anak. Kalau anak mendapatkan start yang baik dalam keluarga, maka akan dapat dengan mudah masuk dalam kehidupan berikutnya yang lebih luas. Keluarga adalah "critical system" tempat anak belajar bagaimana memuaskan kehidupanya dan bagaimana menghadapi dunia.

Setiap anak mulai belajar melalui lingkungan terdekatnya, terutama melalui kontak dengan ibunya. Selanjutnya melalui kontak dengan ayahnya serta anggota keluarga lainnya, dan baru kemudian secara bertahap belajar melalui lingkungan yang lebih luas. Jika keluarga sebagai start awal sebagai tempat pertama belajar anak sudah tidak mendukung, dikhawatirkan pada tahap berikutnya yang lebih luas anak akan mengalami hambatan. Dan hal tersebut dapat berdampak pada terhambatnya perkembangan anak baik potensi maupun psikologis anak.

Hal ini ditegaskan oleh Sunardi dan Sunaryo (2007:22) yang menyatakan bahwa orang tua yang kurang menjalankan fungsi, peran dan tanggung jawabnya sebagai peletak dasar bagi perkembangan optimal anak, yang juga sering berdampak pada krisis psikologis dan sosial yang berlarut-larut yang pada akhirnya bermuara pada terhambatnya respon positif dan konstruksi terhadap kekurangan yang dialami anak.

\section{Penanganan Speech or Language Disorder pada} Anak

Apa yang perlu dilakukan orang tua, apabila anak menunjukkan ciri-ciri atau tanda-tanda di atas atau mengalami gangguan komunikasi (bicara atau bahasa)?

1. Membawa anak kepada tenaga ahli yang berkaitan dengan kelainan pada anak. Dari tenaga ahli tersebut, orang tua, keluarga dapat mengetahui anak mereka masuk kategori gangguan komunikasi jenis apa, apa penyebabnya, dan apa yang harus dilakukan.

2. Sesering mungkin mengajak anak untuk bercerita, berkomunikasi dua arah (parallel talk), memperbanyak latihan dengan menggunakan media visual/gambar.

3. Memberi kesempatan anak untuk melakukan sesuatu secara mandiri atau 
235 Peran Orang tua dan Keluarga dalam Penanganan Anak dengan Gangguan Komunikasi (Bicara atau Bahasa)- Uyu Mu'awwanah, Asep Supena

DOI : https://doi.org/10.31004/basicedu.v5i1.620

tidak segera dibantu.

4. Memasukkan anak ke sekolah yang sesuai dan kembangkan potensi yang dimiliki anak.

5. Bersikap proaktif (lebih aktif) atas perlakuan yang diberikan kepada anak.

Penanganan keterlambatan bicara memerlukan waktu yang agak lama serta kerja sama yang baik dari orang tua. Beberapa anak tidak memperoleh penanganan dengan baik sampai masalah perkembangan itu menjadi sesuatu yang tidak dapat ditangani atau berdampak secara signifikan terhadap hal-hal lain (Majnemer A, dkk 2006: 118). Keterlambatan bicara sering disertai gangguan lainnya sesuai dengan penyakitnya seperti hiperaktif, tingkah laku yang aneh, sulit untuk diajak kerjasama, maka penanganannya harus dimulai dengan memperbaiki perilakunya. Setelah itu baru bisa diberikan terapi yang mendukung seperti terapi wicara, terapi okupasi, terapi sensori integrasi, dll. Sunanik (2013: 23) mengemukakan penanganannya memerlukan kerja sama dari berbagai ahli seperti fisioterapis, ahli terapi okupasi selain tentunya ahli terapi wicara.

Dalam penanganan anak berkebutuhan khusus dilakukan terapi wicara dan sensori integrasi. Terapi wicara digunakan untuk menangani anak dengan gangguan komunikasi hal ini sering dideteksi terlambat bicara. Untuk itu diperlukan terapi wicara dengan melatih wicara anak agar anak dapat berkomunikasi dengan masyarakat. Terapi ini untuk melatih anak terampil mempergunakan sistem encoding berupa kemampuan mempergunakan organ untuk bicara, menggerakkan lengan tangan dan tubuh yang lain, serta ekspresi wajah. Sedangkan dalam pengetahuan anak diharapkan mampu mengerti tentang cara mengucapkan seluruh bunyi bahasa dengan benar, mengevaluasi bicaranya sendiri berdasarkan pengamatan visual, auditori, dan kinestetis. Sementara untuk sikap diharapkan anak berperilaku baik terhadap orang lain sehingga emosi anak berkembang seimbang.

Terapi sensori integrasi adalah proses neurological yang mengorganisasikan sensori dari tubuh seseorang dan dari lingkungan. Pengorganisasian ini akan memungkinkan tubuh merespon lingkungannya secara efektif. Terapi ini juga mengintegrasikan informasi sensori yang akan digunakan melalui sensori (sentuhan, kesadaran, gerakan tubuh, keseimbangan dan gravitasinya, pengecapan, penglihatan dan pendengaran), memori dan knowledge. Semua itu disimpan di otak untuk menghasilkan respon bermakna.

Peran dokter disini sangat penting dalam membantu memberikan keterampilan kepada orang tua untuk dapat menetapkan kebutuhan anak. Satu hal penting yang perlu diingat oleh setiap orang tua adalah bahwa setiap anak memiliki kebutuhan yang berbeda dari anak lain. Greenspan (1998) menekankan bahwa setiap anak memiliki profil yang unik dan spesifik. Individual differences (perbedaan individu) ini tertampil pada: (a) bagaimana anak memproses informasi (gaya belajar), bereaksi terhadap sensasi, merencanakan tindakan, dan merunut perilaku atau pikiran mereka; (b) derajat kapasitas fungsi emosional, sosial dan intelektual mereka; (c) pola interaksi 
236 Peran Orang tua dan Keluarga dalam Penanganan Anak dengan Gangguan Komunikasi (Bicara atau Bahasa)- Uyu Mu'awwanah, Asep Supena

DOI : https://doi.org/10.31004/basicedu.v5i1.620

dan komunikasi mereka; (d) kepribadian mereka; dan (e) pola pengasuhan keluarga mereka.

\section{Pendidikan Khusus untuk Penderita Speech or Language Disorder}

Berdasarkan Undang-undang Dasar 1945 pasal 31 ayat 1 dan Undang-undang Nomor 20 tahun 2003 tentang Sistem Pendidikan Nasional dapat disimpulkan bahwa negara memberikan jaminan sepenuhnya kepada anak berkebutuhan khusus untuk memperoleh layanan pendidikan yang bermutu. Ini menunjukkan bahwa anak berkebutuhan khusus berhak pula memperoleh kesempatan yang sama dengan anak lainnya (reguler) dalam pendidikan. Selama ini, layanan pendidikan bagi anak berkebutuhan khusus di Indonesia disediakan melalui tiga macam lembaga pendidikan yaitu, Sekolah Luar Biasa (SLB),

Sekolah Dasar Luar Biasa (SDLB), dan Pendidikan Terpadu.

Zaitun (2017: 105), Selama ini anak-anak yang memiliki perbedaan kemampuan (difabel) disediakan fasilitas pendidikan khusus disesuaikan dengan derajat dan jenis difabelnya yang disebut dengan Sekolah Luar Biasa (SLB). Secara tidak disadari sistem pendidikan SLB telah membangun tembok eksklusivisme bagi anak-anak yang berkebutuhan khusus. Tembok ekslusivisme tersebut selama ini tidak disadari telah menghambat proses saling mengenal antara anakanak difabel dengan anak-anak non-difabel. Akibatnya dalam interaksi sosial di masyarakat kelompok difabel menjadi komunitas yang tereliminasi dari dunia kehidupan kelompok difabel. Sementara kelompok difabel sendiri merasa keberadaannya bukan menjadi bagian integral dari kehidupan masyarakat di sekitarnya.

\section{SIMPULAN}

Masalah anak berkebutuhan khusus dengan gangguan komunikasi (bicara dan bahasa) merupakan masalah yang cukup kompleks secara kuantitas maupun kualitas. Mengingat berbagai jenis anak berkebutuhan khusus dengan gangguan komunikasi (bicara dan bahasa), dibutuhkan penanganan secara khusus. Jika anak dengan gangguan komunikasi (bicara dan bahasa) mendapatkan pelayanan yang tepat, khususnya keterampilan hidup (life skill) sesuai minat dan potensinya, maka anak akan lebih mandiri. Namun, jika tidak ditangani secara tepat, maka perkembangan kemampuan anak mengalami hambatan dan menjadi beban orang tua, keluarga, masyarakat dan negara.

Speech or language disorder pada anak umumnya terjadi pada saat usia prasekolah, secara klinis dipastikan pada umur 2 tahun hanya dapat mengucapkan kurang dari 50 kata dan/ atau belum ada kalimat yang terdiri dari kombinasi dua kata. Penyebab speech or language disorder sangat luas sekali mulai dari faktor medis sampai faktor lingkungan turut Sandil menjadi penyebab masalah gangguan pada anak ini. Deteksi dini perlu dilakukan terutama apabila bayi tidak menunjukkan tanda-tanda kenormalan, disaat usianya yang sudah seharusnya mampu melakukan sesuatu, seperti di usia 6 bulan, anak seharusnya mampu memalingkan mata serta kepalanya terhadap suara yang datang dari belakang atau samping. Maka ini menjadi langkah awal untuk 
237 Peran Orang tua dan Keluarga dalam Penanganan Anak dengan Gangguan Komunikasi (Bicara atau Bahasa)- Uyu Mu'awwanah, Asep Supena

DOI : https://doi.org/10.31004/basicedu.v5i1.620

penanganan lanjutan, tujuan tak lain supaya anak dapat segera ditangani sedini mungkin.

Orang tua atau keluarga sebagai pemberi layanan utama terhadap anak berkebutuhan khusus dengan gangguan komunikasi (bicara dan bahasa), pada umumnya masih kurang mempunyai kesadaran dan tanggung jawab untuk memberikan persamaan hak dan kesempatan bagi anak-anak tersebut. Hal ini dikarenakan kurangnya pengetahuan orang tua atau keluarga tentang bagaimana merawat, mendidik, mengasuh dan memenuhi kebutuhan anak-anak tersebut. Orang tua atau keluarga merupakan faktor terpenting dalam memfasilitasi tumbuh kembang dan perlindungan anak berkebutuhan khusus.

\section{DAFTAR PUSTAKA}

Anggito, A., \& Setiawan, J. 2018. Metodologi penelitian kualitatif. Sukabumi: CV Jejak (Jejak Publisher).

Azwar. 2013. Deteksi Dini Keterlambatan Bicara dan Gangguan Bahasa Pada Anak, Majalah Ikatan Dokter Indonesia, edisi VIII, November.

Deputi Bidang Perlindungan Anak (2011). Peraturan Menteri Negara Pemberdayaan Perempuan dan Perlindungan Anak Republik Indonesia, Nomor 10 Tahun 2011 tentang Kebijakan Penanganan Anak Berkebutuhan Khusus. Jakarta: Kementerian Pemberdayaan Perempuan dan Perlindungan Anak Republik Indonesia.

Direktorat Pembinaan Pendidikan Anak Usia Dini, Direktorat Jenderal Pendidikan Anak Usia Dini 2011. Orang tua dengan Anak yang Berkebutuhan Khusus. Nonformal dan Informa. Jakarta: Kementerian Pendidikan Nasional.

Edi, Handoko. 2016. Deteksi Dini Gangguan Pendengaran Pada Bayi Dan Anak, dalam Early Detection For The Bright Future,
Lab/SMF Ilmu Kesehatan Anak FKUB-RSU dr. Saiful Anwar - Malang IDAI Cabang JawaTimur Komisariat JATIM V, Malang.

Estabrooks. W. 1994. Auditory Verbal Therapy for Parents And Professionals. Washington DC, U.S.A.: Alexander Graham Bell Association for the deaf.

Fadhil, Aulia. 2010. Buku Pintar Kesehatan Anak: optimalkan pertumbuhan mental dan fisik, Yogyakarta: pustaka anggrek.

Hallahan, Daniel R.dan James M. Kauffman, (2006). Exceptional Learners, Introduction to Special Education. Boston: Pearson Education Inc. International Institute for Educational Planning.

Hartanto, William Surya. 2018. Deteksi Keterlambatan Bicara dan Bahasa pada Anak, CDK-266/ vol. 45 no. 7 th.

https://sahabatkeluarga.kemdikbud.go.id/laman/ind ex.php?r=tpost $\% 2$ Fxview\&id=3360

https://www.un.org/development/desa/disabilities/ convention-on-the-rights-of-persons-withdisabilities.html

Inclusive Education: What, Why, And How, A Handbook for Program Implementers, London: St Vincent House, 30 Orange Street. 2016.

Jasaputra, Diana Krisanti. 2003. Gangguan Sistem Imun pada Anak Autistik, JKM. Vol. 2, No.2,Februari.

Jauhari, M. N., \& Rafikayati, A. (2019). Keterlibatan Orang tua Dalam Penanganan Anak.

https://www.researchgate.net/publication/336 845546

Kirk, Samuel, dkk. 2009. Educating Exceptional Children, Boston: Houghton Miffl in Harcourt Publishing Company.

Kusumawati, Anisyah. Waspada, Ajarkan Dua Bahasa Bisa Membuat Anak Terlambat Bicara, https://nakita.grid.id/read/02207307/waspadaajarkan-dua-bahasa-bisa-membuat-anakterlambat-bicara?page $=$ all

Lisinus, Rafael dan Pastiria Sembiring. 2020. Pembinaan Anak Berkebutuhan Khusus: 
238 Peran Orang tua dan Keluarga dalam Penanganan Anak dengan Gangguan Komunikasi (Bicara atau Bahasa)- Uyu Mu'awwanah, Asep Supena

DOI : https://doi.org/10.31004/basicedu.v5i1.620

Sebuah Perspektif Bimbingan dan Konseling, Medan: Yayasan Kita Menulis.

Madyawati, Lilis. 2017. Strategi Pengembangan Bahasa Pada Anak, Jakarta: Kencana.

Milles, \& Huberman. 2013. Qualitative Data Analysis: A Methods Sourcebook. Los Angeles: SAGE Publications.

Moleong, L. 2017. Metodologi Penelitian Kualitatif. Bandung: PT Remaja Rosdakarya. Dipetik Desember 5, 2019

Peraturan Menteri Pendidikan Dan Kebudayaan Republik Indonesia Nomor 157 Tahun 2014 Tentang Kurikulum Pendidikan Khusus.

Pieter, Heri Zan. 2017. Dasar-Dasar Komunikasi bagi Perawat, Jakarta: Kencana.

Pusponegoro, Hardiono D. Specific Language $\begin{array}{llll}\text { Impairment } & \text { (SLI), } & h . & \end{array}$ https://staff.ui.ac.id/system/files/users/hardion o.pusponegoro/publication/specific_language impairments.pdf

Rakhmanita, Elsa. 2020. Kajian Psikolinguistik terhadap Gangguan Berbahasa Autisme, 5 januari, lihat https://osf.io/preprints/inarxiv/s8mu5/

Sri Winarsih, Sri, Dra. dkk. 2013. Panduan Penanganan Anak Berkebutuhan Khusus Bagi Pendamping (Orangtua, Keluarga, Dan Masyarakat) Jakarta: Kementerian Pemberdayaan Perempuan dan Perlindungan Anak Republik Indonesia.

Sugiyono. 2018. Metode Penelitian : Kuantitatif, Kualitatif, dan $R \& D$. Bandung: Alfabeta. Dipetik Desember 5, 2019

Sunardi dan Sunaryo. 2007. Intervensi Dini Anak Berkebutuhan Khusus. Jakarta: Depdiknas

Sularyo, Titi Sunarwati dan Muzal Kadim. 2000. Retardasi Mental. Sari Pediatri, Vol. 2, No. 3, Desember.

Sunanik. 2013. Pelaksanaan Terapi Wicara dan Terapi Sensori Integrasi pada Anak Terlambat Bicara, Nadwa. Jurnal Pendidikan Islam Vol. 7, Nomor 1, April.

Tantiani, Farah Farida. 2020. Keterlibatan Orang tua dalam Intervensi Anak Berkebutuhan
Khusus. Jurnal Sains Psikologi Vol. 9, Nomor 1, Maret

Undang Undang Dasar 1945 pasal 31 ayat 1 dan Undang-Undang Nomor 20 tahun 2003 tentang Sistem Pendidikan Nasional.

Zaitun. 2017. Pendidikan Anak Berkebutuhan Khusus. Pekanbaru: Kreasi Edukasi. 